\title{
OVARIAN FUNCTION IN THE COW AFTER INDUCTION OF UTERINE MOTILITY
}

\author{
S. L. OXENREIDER \\ Department of Animal Science, Iowa State University, \\ Ames, Iowa 50010, U.S.A.
}

(Received 13th November 1967)

The length of the oestrous cycle is reduced in the cow following daily subcutaneous injections of oxytocin during the week after oestrus (Armstrong \& Hansel, 1959) but not after hysterectomy (Armstrong \& Hansel, 1959; Anderson, Bowerman \& Melampy, 1965). Ginther (1967) reported a unilateral luteolytic effect of the uterus in cows given oxytocin, suggesting a local uteroovarian mechanism.

The uterus of the non-pregnant cow exhibited considerable muscular activity soon after intravenous injection of oxytocin (Simmons, Dracy \& Essler, 1965). Uterine contractions became tetanic and began to subside $17 \mathrm{~min}$ later. Armstrong \& Hansel (1959) have suggested that uterine afferent impulses may influence indirectly the secretion of hypophysial luteotrophin after the injection of oxytocin. It has been shown that electrical stimulation through the rectum can induce oestrous activity in anoestrous cows (Hays \& Carlevaro, 1959). In the present study, uterine contractions were induced by electrical stimulation to determine if resulting uterine afferent impulses reduce the period of luteal maintenance.

Electrical stimulation of the uterus through the rectum was produced by an electro-ejaculator (Model E2X1, Plectron Corporation). Uterine motility was evaluated in four heifers by laparotomizing them and palpating the uterus during electrical stimulation. The stimulation was applied for 15 or $20 \mathrm{~min}$ at 8-hr intervals during the first 7 days of the oestrous cycle in thirteen heifers. One heifer was stimulated for $2 \frac{1}{2} \mathrm{hr}$ once daily during this period. Frequencies of 20,30 or 45 cycles/sec were used.

Four methods (A, B, C and D) of applying electrical stimulation were used in an attempt to find a scheme for causing a reduction of the oestrous cycle. In method $\mathrm{A}$, the voltage was advanced slowly during $5 \mathrm{sec}$ and then was decreased slowly to zero during $5 \mathrm{sec}$, with a rest period of $10 \mathrm{sec}$ between stimulations. It was increased $\frac{1}{4}$ volt each time the stimulus was applied, to a maximum of approximately 13 volts. Maximal voltage then was applied rhythmically until the end of the stimulation period. Method B was the same as $A$, except that the maximum voltage was 4 . Method $\mathrm{G}$ was the same as $\mathrm{A}$, except that the rest period was $15 \mathrm{sec}$ between 6 and 9 volts and $20 \mathrm{sec}$ at voltages greater than 9 . In method $D$, the voltage was increased slowly to $2 \frac{1}{2}$ and held at that level, without rest periods, for the duration of the stimulation period. 
Before giving oxytocin to one heifer the lumbar and sacral nerves were anaesthetized to block most uterine afferent impulses. Each day, $150 \mathrm{ml}$ of $2 \%$ procaine hydrochloride was infused into the epidural space through an indwelling polyethylene cannula (Bierschwal, 1960) $30 \mathrm{~min}$ before subcutaneous injection of $0.476 \mathrm{USP}$ units oxytocin $/ \mathrm{kg}$ body weight (Anderson et al., 1965). Procaine was infused during a period of $90 \mathrm{~min}$, and anaesthesia persisted for $30 \mathrm{~min}$ after infusion. The extent of anaesthetization was determined by pricking the skin. Cutaneous afferent nerves were anaesthetized caudal to the thirteenth thoracic vertebra.

Two heifers were hypophysial stalk transectioned by the method of Anderson \& Oxenreider (1967) on the day after the onset of oestrus. The importance of vascular connexions between the hypothalamus and hypophysis on the induction of luteal failure by exogenous oxytocin was evaluated in these animals. Oxytocin was injected subcutaneously $(0.476$ USP units $/ \mathrm{kg}$ daily) for

\section{TABLE 1}

OESTROUS GXGLES IN HEIFERS AFTER ELEGTRICAL STIMULATION THROUGH THE REGTUM

\begin{tabular}{|c|c|c|c|c|c|c|c|}
\hline \multirow{2}{*}{$\begin{array}{l}\text { No. of } \\
\text { heifers }\end{array}$} & \multirow[b]{2}{*}{ Treatment } & \multicolumn{6}{|c|}{ Oestrous cycle length (days) } \\
\hline & & $\begin{array}{l}\text { Before } \\
\text { Averag }\end{array}$ & $e^{\text {stimulation }}$ & $\begin{array}{r}S t \\
\text { Avera }\end{array}$ & $\begin{array}{l}\text { zulation } \\
\text { Range }\end{array}$ & $\begin{array}{l}\text { After } \\
\text { Averag }\end{array}$ & $\begin{array}{l}\text { timulation } \\
\text { Range }\end{array}$ \\
\hline 12 & $\begin{array}{l}\text { Electrical stimulation } \\
\text { at } 8 \mathrm{hr} \text { intervals* }\end{array}$ & $20 \frac{1}{2}$ & 18 to 23 & $20 \frac{1}{2}$ & 17 to 23 & 21 & 18 to 24 \\
\hline 2 & $\begin{array}{l}\text { Electrical stimulation } \\
\text { at } 8 \mathrm{hr} \text { intervals }\end{array}$ & $19 \frac{1}{2}$ & 18 to 22 & 27 & 27 to 27 & 22 & 20 to 24 \\
\hline 1 & $\begin{array}{l}\text { Probe placed in rectum, } \\
\text { no electrical stimulation }\end{array}$ & $23 \frac{1}{2}$ & 21 to 25 & 25 & - & 20 & 19 to 21 \\
\hline
\end{tabular}

* One heifer was stimulated for periods of $2 \frac{1}{2} \mathrm{hr}$ at intervals of $24 \mathrm{hr}$.

6 days following surgery. Jugular vein blood was collected at the 6 th day and again at the 10th day after surgery. Ovarian venous blood and luteal tissue were obtained by laparotomy at the 10th day and analysed for progesterone as described by Masuda, Anderson, Henricks \& Melampy (1967). Progesterone in peripheral blood was quantified by gas-liquid chromatography as described by Hashimoto, Henricks, Anderson \& Melampy (1968).

In the laparotomized heifers, electrical stimulation by methods $\mathrm{A}, \mathrm{B}$ and $\mathrm{C}$ produced uterine contractions in both horns simultaneously 5 to $6 \mathrm{sec}$ after the stimulus was applied. These contractions occurred whenever the stimulus was applied and were followed in most instances with complete relaxation of the myometrium as the current was withdrawn. Contractions induced by method D were similar to spontaneous ones (uterine horns contracted asynchronously) for $9 \mathrm{~min}$. After 9 min the uterus became tetanic.

Spontaneous contractions were unchanged until 5 min after the injection of oxytocin, and then they became tetanic. This tetanic state was similar to that observed with electrical stimulation (method D).

Oestrous cycles were 17 to 23 days in twelve of fourteen heifers in which uterine contractions were induced by electrical stimulation during the week 
following oestrus (Table 1). Two heifers had cycles of 27 days. Rectal palpation indicated normal morphological development and regression of the corpus luteum in all animals.

Anaesthetization of the lumbo-sacral spinal nerves did not prevent the induction of luteal regression by exogenous oxytocin. A small corpus luteum was identified by rectal palpations and the heifer returned to oestrus on Day 9 of the cycle.

On the 6th day after hypophysial stalk transection (Day 8 of oestrous cycle) the levels of progesterone in the peripheral blood of two heifers were 486 and $415 \mathrm{ng} / 100 \mathrm{ml}$ blood. These were similar to a level of $442 \mathrm{ng}$ in an unoperated heifer receiving oxytocin, but considerably higher than those in uninjected stalk-transectioned heifers $(172 \pm 13 \mathrm{ng})$ and intact control animals $(254 \pm$ $30 \mathrm{ng}$ ) at the same stage of the oestrous cycle (Henricks, Oxenreider, Anderson \& Guthrie, 1967). By Day 10, control as well as uninjected stalk-transectioned animals had greater concentrations of progesterone in the peripheral blood than at Day 6, but the oxytocin-treated heifers had low values (17 and 21 $\mathrm{ng} / 100 \mathrm{ml}$ blood in the stalk-transectioned animals and $55 \mathrm{ng} / 100 \mathrm{ml}$ blood in the unoperated heifer). Progesterone was not detected at Day 10 in the ovarian venous blood of the two hypophysial stalk-transectioned heifers that were injected with oxytocin. The corpora lutea of these animals weighed 0.51 and $0.38 \mathrm{~g}$ at Day 10 compared with an average weight of $2.8 \pm 0.14 \mathrm{~g}$ in untreated stalk-transectioned animals (Anderson, Oxenreider, Henricks \& Melampy, 1966). One heifer had $20.2 \mu \mathrm{g}$ progesterone/mg of luteal tissue, and no progesterone was detected in the corpus luteum of the other animal.

Results of this study indicate that uterine contractions induced by electrical stimulation are ineffective in causing luteal failure in the beef heifer. In most instances, the total stimulation time was $1 \mathrm{hr} /$ day and this was divided into three periods of $20 \mathrm{~min}$ each. Since intravenous injection of oxytocin causes the uterus to contract for $17 \mathrm{~min}$, it is probable that the effects of oxytocin given subcutaneously would last longer than $20 \mathrm{~min}$. A stimulation period of $2 \frac{1}{2} \mathrm{hr} /$ day, however, did not affect the oestrous cycle of one heifer stimulated continuously with $2 \frac{1}{2}$ volts. This method of stimulation produced tetanic contractions similar to those produced by oxytocin. The corpus luteum regressed after the injection of oxytocin even though the lumbo-sacral spinal nerves were anaesthetized. These nerves are a pathway for afferent impulses from the uterus.

Corpora lutea also regressed prematurely in hypophysial stalk-transectioned heifers injected with oxytocin, whereas oestrous cycles were unchanged by electrically-induced uterine contractions. It appears, then, that early failure of the corpus luteum caused by exogenous oxytocin is dependent neither on the influence of uterine afferent nerve impulses nor on hypothalamic control of hypophysial function.

Thanks are due Dr R. M. Melampy for advice, Dr L. L. Anderson for hypophysial stalk transections and advice and Dr D. M. Henricks for progesterone analyses. This work was supported by United States Department of Agriculture, Cooperative State Research Service Grant 427-15-8; National Institutes of Health Grant HD 01 168-08 and by American Cyanamid Company, 
Princeton, New Jersey. Journal Paper No. J-5816 of the Iowa Agricultural and Home Economics Experiment Station, Ames, Iowa (Project No. 1593).

\section{REFERENCES}

Anderson, L. L., Bowerman, A. M. \& Melampy, R. M. (1965) Oxytocin on ovarian function in cycling and hysterectomized heifers. F. Anim. Sci. 24, 964.

ANDERson, L. L. \& OXENREIDER, S. L. (1967) A technique for hypophysial stalk transection in the cow. F. appl. Physiol. 23, 762.

Anderson, L. L., Oxenreider, S. L., Henricks, D. M. \& Melampy, R. M. (1966) Pituitary stalksection in beef heifers. F. Anim. Sci. 25, 1262.

ARmstrong, D. T. \& HANSEL, W. (1959) Alteration of the bovine estrous cycle with oxytocin. $\mathcal{F}$. Dairy Sci., 42, 533.

Bierschwal, C. J. (1960) A technic for continuous epidural anesthesia in the bovine. Vet. Med. 55, 44.

Ginther, O. J. (1967) Local utero-ovarian relationships. F. Anim. Sci. 26, 578.

Hashimoto, I., Henricks, D. M., Anderson, L. L. \& Melampy, R. M. (1968) Progesterone and pregn-4-ene-20 $\alpha$-ol-3-one in ovarian venous blood during various reproductive states in the rat. Endocrinology, 82, 333.

Hays, R. L. \& Carlevaro, C. H. (1959) Induction of estrus by electrical stimulation. Am. F. Physiol. 196, 899.

Henricks, D. M., Oxenreider, S. L., Anderson, L. L. \& Guthrie, H. D. (1967) Progesterone in systemic and ovarian venous blood and corpora lutea of cycling, hypophysial stalk sectioned, stalk sectioned hysterectomized and stalk sectioned oxytocin treated cows. Fedn Proc. Fedn Am. Socs exp. Biol. 26, 366.

Masuda, H., Anderson, L. L., Henricks, D. M. \& Melampy, R. M. (1967) Progesterone in ovarian venous plasma and corpora lutea of the pig. Endocrinology, 80, 240.

Simmons, K. R., Dracy, A. E. \& EssLer, W. O. (1965) Recording uterine activity by radio telemetry techniques. 7. Dairy Sci. 48, 1126. 